\title{
Accommodating revisionism through balancing regionalism: the case of Central Asia
}

\author{
Aliya Tskhay and Filippo Costa Buranelli
}

\begin{tabular}{|c|c|}
\hline Date of deposit & 11022020 \\
\hline Document version & Author's accepted manuscript \\
\hline Access rights & $\begin{array}{l}\text { Copyright @ } 2020 \text { University of Glasgow. This work is made } \\
\text { available online in accordance with the publisher's policies. This is } \\
\text { the author created, accepted version manuscript following peer } \\
\text { review and may differ slightly from the final published version. }\end{array}$ \\
\hline $\begin{array}{l}\text { Citation for } \\
\text { published version }\end{array}$ & $\begin{array}{l}\text { Tskhay, A., \& Costa Buranelli, F. (2020). Accommodating } \\
\text { revisionism through balancing regionalism: the case of Central } \\
\text { Asia. Europe-Asia Studies, Latest Articles. }\end{array}$ \\
\hline $\begin{array}{l}\text { Link to published } \\
\text { version }\end{array}$ & https://doi.org/10.1080/09668136.2020.1779184 \\
\hline
\end{tabular}

Full metadata for this item is available in St Andrews Research

Repository at: https://research-repository.st-andrews.ac.uk/

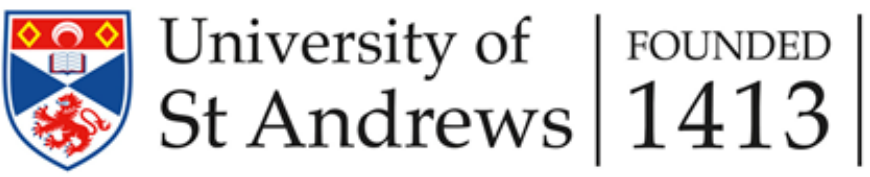


Accommodating revisionism through balancing regionalism: the case of Central Asia

\section{Introduction}

The idea of an inclusive multilateral world order based on the primacy of international law, promotion of democracy, protection of human rights, and free trade rules, so enthusiastically embraced by Western governments and supported by a consistent part of academics and pundits after the end of the Cold War, seems to be weakening. Paraphrasing Francis Fukuyama, one may say that this may be the end of that history, but not of 'History' per se. A new phase of (re)structuration of international order, both from a material and a normative perspective, is ongoing. As Russian foreign minister Sergei Lavrov has argued, 'humanity stands at a crossroads today. The historic era that could be called the post-Cold War order has come to an end. ${ }^{1}$

Current academic and diplomatic discourses tend to depict this critical juncture using the term 'revisionism', mostly associated to Russia's behaviour in the international system and in its immediate regional neighbourhood. But what is 'revisionism', exactly? Revisionism is a term that, necessarily, involves the consideration of two conflicting temporal dimensions: how things are developing at the moment of speaking and/or writing, and how things would be in a desired future, at least in the mind of the revisionist state(s). The term, originated within Marxist theory, usually identifies a set of thoughts, behaviours, practices, principles, and doctrines, that more or less openly challenges established norms in a given social domain (be it a society, an institution, an academic field) and claims for reverting to a new order of things. The etymology of the word, with 'visio' indicating a set of ideas and, in fact, a 'vision', and the prefix '-re' indicating a change, a novelty of condition, well conveys the idea of 'reversal' or 'restructuring' included in the concept of revisionism.

While Russia's revisionism at the international level has received considerable attention within academic circles (Allison 2017, Sakwa 2017, see, e.g., Richey 2018), very little research has so far been produced in regard to how this revisionism has affected Russia's relations with its fellow CIS partners and, more specifically, with the Central Asian republics, defined in this paper as Kazakhstan, Kyrgyzstan, Tajikistan, Turkmenistan, and Uzbekistan (for a partial exception, see Costa Buranelli 2017; Allison 2017).

To be sure, Russia's revisionism has not gone unnoticed in the region. Aidos Sarym, a political analyst in Central Asia, has recently argued that to solve some internal issues Russia could quite probably take action like it did in Ukraine's Donbass [eastern region]. I think we should worry about it. Therefore Kazakhstan should review its defence doctrine and foreign policy, find ways to protect ourselves, get stronger internally.' Another prominent expert, Dosym Satpayev, has maintained that "because of "jingoistic psychosis" in Russia, we can see that the Russian political elite already perceives its partners as satellites. I mean Kazakhstan, Belarus, Kyrgyzstan and Armenia [members of the Eurasian Economic Union

\footnotetext{
${ }^{1}$ Foreign Minister Sergey Lavrov's address and answers to questions at the 53rd Munich Security Conference, Munich, $\quad$ February 18, 2017 (available at http://www.mid.ru/en/press_service/minister_speeches//asset_publisher/7OvQR5KJWVmR/content/id/2648249)
} 
(EAEU)]'. Tolganay Umbetaliyeva, head of the Kazakhstan-based Central Asian Fund for Development of Democracy, has said that it is clear that Russia is not going to sit around and watch us cooperate. Possibly, it is going to interfere; therefore Kazakhstan is going to face some issues [with Russia]'.2

This paper aims to contribute to a broader understanding of how current Russia's revisionism is impacting Central Asia. To do so, the paper advances the argument that, to counter Russia's revisionism, the Central Asian republics engage in what we call 'balancing regionalism', defined as the act of countering a neighbouring country's aggressive foreign policy not by directly balancing it militarily or economically, but rather by acting on a number of regional organisations, promoting dialogue between them, and fostering a number of additional regional platforms that help relax ties and obligations towards that preponderant state and increase costs for revisionism itself. The above, we argue, happens by means of three different mechanisms, which will be explored later in the paper - bridging, dovetailing, and branding. It is crucial to specify from the very beginning that the notion of "balancing regionalism' does not imply an outright rejection of Russia as a regional actor - the Central Asian republics are too well aware of the military, economic, and historical significance of Russia in Eurasia. What the term implies, conversely, is a more nuanced understanding of international relations, one that eludes the 'acceptance/rejection' dichotomy and, instead, embraces the possibility of dealing with Russia making it part of a wider constellation of actors organised along regional lines.

To illustrate how balancing regionalism works in Central Asia, we rely on Stacey Goddard's theoretical framework of 'embedded revisionism' (2018), as well as on the recent study by Cooley and collaborators (2019). Such conceptualisations of revisionism are the object of the next section. Then, the paper moves to a discussion of what 'balancing regionalism' means, and what mechanisms underpin it. The third part of the paper discusses some empirical examples of balancing regionalism, while the fourth one considers the implications thereof. In the conclusions, we recap the argument, point at its strengths and weaknesses, and indicate potential avenues for new research.

Methodologically, rather than focusing intensively on a specific set of case studies, the paper will discuss the relevance of 'balancing regionalism' providing the reader with a series of different examples coming from the region, focusing on official discourses and policies. While there is limited scope to elaborate fully on this notion and on these examples, the hope, however, is that these instances and incipient theorisation will serve for further theorisation around the concept of 'balancing regionalism' and of the significance thereof in countering revisionism in Eurasia.

\section{Conceptualising Revisionism in Eurasia}

In the introduction, revisionism was defined as a reaction to an ordered set of principles, ideas, norms, and behaviours to reaffirm, recreate, re-establish a different set of practices,

\footnotetext{
2 All quotes from 'Putin's re-election not good news for Central Asia - pundits', BBC Worldwide Monitoring, 22 March 2018, available https://www.nexis.com/search/EnhXMLCrossLinkSearch.do?ersKey=23 T27729495578\&returnTold= 20 T27729499017\&csi $=10962 \& A=0.018261650288989295 \&$ sourceCSI $=162599 \&$ indexTerm $=\% 23 \mathrm{PE}$ 0009U46\%23\&searchTerm=Vladimir\%20Putin's\%20\&indexType=P, accessed 18 July 2018.
} 
arguably in contrast to those established at present. Yet, one may ask - what counts exactly as 'revisionism'? Who can be defined as 'revisionist'? And is there only one form of revisionism (see also $X$ and $Y$ in this special issue)? In the words of Goddard, 'revisionists are states that seek to challenge, in whole or in part, the international institutional order - the settled rules and arrangements between states that define and guide their interaction' (2018, p. 3). Cooley et al. (2019), in their recent sharp treatment of the concept, also link revisionism to change and to redistribution, either of the balance of power, or of the normative structure of international society, or both (that is, for material and non-material gains).

In order to illustrate how Central Asian states accommodate Russia's revisionism through balancing regionalism as defined above, we base our argument on Stacie Goddard's theory of embedded revisionism (2018) and on Cooley et al.'s analytical treatment of revisionism (2019), thus combining the two perspectives. Goddard maintains that revisionist powers, at the systemic level, have to check their chances to succeed in revisioning international politics against the present-day institutional order, conceived of as a relational network. The position that this revisionist power has in the network 'alters the costs and benefits of revisionist strategies, making certain forms of revisionism more attractive than others' (2018, p. 2). She then builds a typology of revisionisms, built on two analytical components: 'access', defined as 'the extent to which a revisionist is integrated into the dominant network, measured by the density and frequency of its institutionalised relations' (2018, p. 7); and 'brokerage', i.e. the ability to create and mobilise ties across different networks. When both access and brokerage are high, revisionism is bridged; when access is high and brokerage is low, it is integrated; when access is low and brokerage is high, it is isolated; and when both components are low, revisionism is rogue.

Yet, we see two problems with this. The first one is that, by virtue of being systemic and structural, this approach neglects almost by definition sub-global networks. In other words, Goddard's approach explains a great deal at the international level, but not at the regional level, where rather than a network we have networks. Second, Goddard's approach speaks of networks without looking at norms, principles, and rules as possible elements for revisionism, too, which keep regional networks together and coherent and make revisionism more costly in terms of legitimacy of the new set of rules (Thomas 2017).

What Cooley and collaborators add to this framework is the multifacetedness of revisionism itself, something that also $X$ does in this special issue (2019). They invite scholars to problematise revisionism breaking it up into four manifestations: status-quo actors, who are satisfied with both order and the distribution of power; reformist actors, who are fine with the current distribution of power but seek to change elements of order; positionalist actors, who see no reason to alter the international order but do aim to shift the distribution of power; and revolutionary actors, who want to overturn both international order and the distribution of capabilities. Therefore, by combining these two complex frameworks, one has a more finegrained reading of revisionism as a complex social phenomenon - not only the conditions allowing for it are better specified (Goddard's model), but also the different aims and identities of the revisionist power(s) are better illustrated (Cooley et al.'s model). 
The flexibility of the framework devised above then allows us to bring levels of analysis into discussion. As a matter of fact, while great power powers can behave as a 'positionalist' or as a 'status-quo' agent at the international level, it can behave revolutionarily at the regional level, within the geographical scope of its (perceived) influence and great power's rights (Slobodchikoff, 2014; Ohayan 2018; see also X and Y, 'Introduction', in this special issue). This is implicitly recognised by Cooley, when arguing that Russia's efforts to target the liberal order on a regional level represents a lower-cost form of power politics that, in practice, does not depend on its appeal as a positive international role model (2019, p. 591), while at the same time recognising that to forcefully annex territory in 2014 signals counter-order revisionism (whether more reformist or more revolutionary) (Cooley et al. 2019, p. 11). Therefore, with respect to Russia, one may identify two sets of revisionist policies, which seem interestingly at odds with each other (Kaczmarska 2015, see also Allison 2017).

At the international level, Russia champions the return (or, perhaps more accurately, the protection) of a Westphalian international order. In other words, Russia emphasises the ultimate value of the institution of sovereignty as a bulwark against humanitarian intervention and regime-change disguised as responsibility to protect, supports a conservative, statecentric application of international law, and contests the present unipolar configuration of the international system by advocating a 'democratic', multipolar world order where the great powers act in concert on an equal standing and sharing equal rights and responsibilities. While this is not the exact focus of the paper, it is important to note that this standing at the international level has some analysts to argue that, in fact, Russia is not a revisionist power but, conversely, a status-quo, conservative one, which struggles to challenge the cosmopolitan approaches based on democracy-promotion and human rights enhancement advanced by Western liberal powers (this may be less true since the Trump administration has taken over, however) (see, for example, Cooley 2019; Sakwa 2017, 2019; Schweller 2015).

At the regional level, conversely, Russia has been challenging the above-mentioned principles, deemed to be absolute at the international level but more negotiable at the regional one. A more flexible reading of impenetrable sovereignty, a selective reading of international law, more subjected to the national interest, and a position of 'primus inter pares' rather than 'omnes pares' seem to be the normative pillars on which Russia founds its conception of regional order. The source of this conflict between two different Weltanschauungen is well explored by Morozov. To him, 'post-Soviet Russia [...] emerged as, and continues to be, a nation whose identity is deeply imprinted with a Eurocentric outlook and at the same time plagued by post-imperial resentment' (Morozov 2015, p. 28). Russia's ultimate goal is 'to enter international society as a great power, but it still perceives global norms and institutions as externally imposed on it by the hegemonic West. Stigmatisation, ontological insecurity and economic backwardness thus represent different manifestations of the same phenomenon - subaltern imperialism, which prevents Russia from fully identifying itself with the West but at the same time leaves it with no other options than to catch up'. (2015, pp. 28-9).

The above suggests that, while the Central Asian states are comfortable with what Russia champions at the international level, they may be not entirely on board with recent practices in Eurasia and with some of the justificatory language that Russia has used to legitimise territorial annexation and border redrawing. Echoing the position of the Central Asian 
analysts mentioned in the introduction, Nikolay Silayev and Andrei Sushentsov have recently argued that 'Russian scholars and analysts state with increasing frequency that the former Soviet states are not entitled to absolute sovereignty or foreign policy choice, while maintaining the divisions in Georgia, Moldova, and now Ukraine is an important tool for preventing these states from joining the Western alliance system and political orbit'. ${ }^{3}$

While it is always difficult to pin-point a precise chronological starting point for a complex social phenomenon such as 'revisionism', one may argue that 2008 (Georgia) and 2014 (Crimea) represent a valid starting point for theorising about it. ${ }^{4}$ In this, we follow Allison's justification for looking at Russian revisionism in Eurasia - according to him, 2008-2018 is the period when 'the issue of separatism in Eurasia also became more contentious' (see also Trenin 2014 in ISPI report). ${ }^{5}$ This is also in line with the other contributions in this special issue, which deal with contemporary discourses of revisionism in Eurasia rather than focusing on a historical perspective. Moreover, Russia's interest in Central Asia (as well as in former Soviet republics, in general) surged after the failure of integration into the West (Trenin, 2009).

\section{Balancing Regionalism and its Operation}

If the above is the regional architecture that Russia has in mind, then it is natural that the Central Asian republics are torn between two opposing vectors of foreign policy: good and cordial relations to avoid irritating the powerful neighbour; diversification of foreign policy relations to avoid an overreliance on Russia and, in fact, to contain it. The latter is known as 'omnibalancing', or 'multivectorism' and has received considerable attention in the literature (David 1991, Fumagalli 2007, Cooley 2012; Nourzhanov 2012, Contessi 2015, Dadabaev 2019, Teles Fazendeiro 2018). Yet, it is exactly here that we want to offer an additional angle of analysis. While the literature has looked at omnibalancing from a bilateral perspective, i.e. looking at how specific Central Asian states engage with China, the US, the EU to avoid partnering only with Moscow, we want to look at how Central Asian states behave in multiple regional organisations and engage in multiple regional platforms simultaneously for strategic purposes (security, economic, and political benefits) without compromising their sovereignty by pooling it. We call this 'balancing regionalism'.

What is meant, exactly, by 'balancing regionalism'? As is evident, the concept is made up of two analytical components - 'balancing', and 'regionalism'. With the former, it is usually meant the accommodation of a superior power, in military and economic terms, so to avoid overreliance, overlay, and domination. Be it understood in Waltzian terms as the ultimate expression of survival of the units and as the fundamental law of international politics (1979) or in English School ones as a social institution, agreed on by the parties, to give international politics a sense of order (Bull 1977, Wight 1977, Little 2007), the idea of 'balancing' ultimately refers to the maintenance of territorial, juridical sovereignty, as well as

\footnotetext{
3 "Russia's Allies and the Geopolitical Frontier in Eurasia," Russia in Global Affairs, 18 May 2017, http://eng.globalaffairs.ru/valday/Russias-Allies-and-the-Geopolitical-Frontier-in-Eurasia-18718)

${ }^{4}$ Cooley (2012, p.51) refers to Russia's 'resurgence' in the region in this period.

5 Yet, one should not dismiss the claim, recently made, that the ideological and strategic motivations for this may lay in an earlier time - As Ivan Krastev noted as early as 2005, the Kremlin regarded Ukraine's "Orange Revolution" as its own "9/11." (quoted in Cooley 2019, p. 599).
} 
to the preservation of a pluralistic community of states and societies. By 'balancing' we do not necessarily mean 'matching military and/or economic capabilities' in a purely realist fashion, but rather 'mixing interests', 'distributing commitments' and 'raising costs' for revisionist strategies. With traditional balance of power theory in mind, one may argue that 'balancing regionalism', being not related to internal military build-up and/or economic growth in order to match an adversary's position in the international system, is a form of 'external balancing'. Yet, it is crucial to avoid thinking that balancing regionalism has anything to do with militarism - the emphasis is much more on multilateral membership, norms, identities, and narratives associated to them, and not on formal military alliances. ${ }^{6}$ Hence, 'balancing regionalism' is not just 'external', but also 'soft' and 'associational' (Little 2007).

By 'regionalism', we mean state-led projects of region-making that often involve a certain degree of institutionalisation, usually (but not necessarily) expressed in the creation of formal regional, inter-national organisations. This latter part of the definition is crucial for the argument of the paper because, within the framework of 'balancing regionalism', the term should be understood as including not just formal regional inter-national organisations, but also informal regional platforms and dialogue(s). The reason for this is the following: establishing dialogue on a regional basis, however informally, is a way that states have to frame themselves (practically but perhaps even more importantly discursively) as belonging to a particular region, or regional group, where specific norms, rules of conduct, codes of behaviour, identities and interests are upheld. After all, as Hameiri has argued, 'at the heart of the politics of regionalisation is the attempt by actors and coalitions to relocate the governance of particular issues beyond the scope of national governance and politics. This rescaling is not incidental, but designed to empower particular interests, while weakening or wholly marginalising others' (2013, p. 314).

It is therefore evident that, in a region like Eurasia where history, identity, and belonging matter to a great extent in the light of the Soviet experience, emphasising the presence of different affiliations, the coexistence of different conceptions of order, and enlarging the discursive as well as the geographical boundaries of the region becomes crucial to make a possible exclusive sphere of influence more difficult to establish and more costly to implement. In other words, 'regionalism becomes an active practice [...] driven by economic, security or multi-purpose logics' (Mikhaylenko 2016, p. 78 emphasis added).

The combination of these understandings of the two terms treated above results in the concept of 'balancing regionalism' meant as a foreign policy tool that the Central Asian states use to achieve three different objectives:

- insulating themselves from excessive great power preponderance and revisionism; this seems to be in line with earlier research, according to which 'even though the Central Asian states may sign up to join regional organizations or other institutional arrangements controlled by Moscow, they will always seek

\footnotetext{
6 In other words, balancing regionalism relies on a logic of 'alignment' rather than of 'alliance' (Nourhanov 2012; Contessi 2015).
} 
alternative partners as a strategic hedge and to provide some protection from and leverage with Moscow (Cooley 2012, p. 68); ${ }^{7}$

- achieving economic and political gains through participation in multilateral formats;

- conforming to the norms of regionalism and multilateralism that are now underpinning international society, as opposed to unilateralism, thus enhancing their international standing and legitimacy (Ruland 2018, p. 1).

Here, a caveat is in order. What we are arguing is not that Central Asian states have suddenly woken up to foreign policy and that balancing regionalism has been born out of the blue. Central Asian states have, since independence, maneuvered in a complex international environment to preserve their sovereignty and independence (and also to project regime legitimacy at the international level). What we are arguing is that, especially since the establishment of the Shanghai Cooperation Organisation (SCO) in the region, and hence of the presence of China as a new great power in the region, as well as in the light of the revisionist dynamics noted above, the use of regional platforms for balancing and hedging purposes has become more prominent and consistent. Our contribution should be taken as the discussion of a trend started in the second half of the 2000 s, rather than as a sudden, reactive foreign policy move (Cooley 2012, p.51; Paul 2016). As a foreign policy tool, balancing regionalism finds its roots in contemporary Russia's revisionism, as noted in the introduction, as well as in Moscow's assertion of having 'privileged interests' in the region (Cooley 2012). The sources of balancing regionalism can in fact be located in what has been called Russia's 'revisionist regionalism' - a form of regionalism that implies revision of the Belavezhskaya Agreements signed in December 1991 (Mikhaylenko 2016).

Another aspect of balancing regionalism that deserves consideration is its status as a foreign policy strategy. In other words - is balancing regionalism the product of a concerted, shared effort to counter revisionism and preserve sovereignty and independence, perhaps discussed in bilateral and multilateral settings by Central Asian leaders, or rather the unintended yet converging outcome of separate national strategies? To begin with, 'balancing regionalism' cannot be found in any multilateral document produced by two or more Central Asian governments. Here, we are clearly resorting inductively to an analytical device. The same, nonetheless, can be said for other, more institutionalised regional groupings, such as ASEAN, where anti-hegemonic behaviour or 'management of the great powers' is visible in practice yet not enshrined in formal legal documents (Goh 2008). To expect Central Asian states to have such a level of coordination in foreign policy coordination would be a serious overestimate of the level of trust and cooperation in the region today.

Yet, it is also undeniable that more often than not Central Asian states do try to carry out balancing regionalism. As Wivel and Waever argue, states 'do not have to agree on the outcome (the classical fallacy in liberal theories of cooperation) but, from within each sensemaking universe, [balancing regionalism] has to be a productive element of each state's "vision of itself"' (2018, p. 321). This signals that there is some sort of standard of behaviour, recognisable in all Central Asian foreign policies. While direct confirmation of anti-

\footnotetext{
7 As Wohlforth notes, 'balancing can also occur against regional states pursuing revisionist policies [...] Here offensive intentions matter more than sheer military capabilities' (Wohlforth 2004, p. 7).
} 
hegemonism through balance of power would require, methodologically speaking, a participant-observation stance or discourse analysis of (un)official meetings between state leaders, diplomats and foreign policy actors in Central Asia, one may also 'spot' its operation in the analysis of repeated diachronic practices, and/or in discourses of blame, opposition and reprimand when a great power is granted excessive preponderance in the region by a regional state. In sum, even with diverse trajectories that Central Asian states take on their regional cooperation, there is a shared identity of 'being at the crossroads' and 'balancers of great powers' which is visible, for example, in the foreign policy concept of each state in the region (Laruelle and Peyrouse 2012).

The last thing to discuss, before moving to the empirical section of the paper is to define the mechanisms through which balancing regionalism operates. A mechanism can be defined, in very simple terms, as a systematic (set of) statement(s) that provide a plausible account of how the practice(s) under inquiry is performed. We argue that there are three mechanisms at play, although we also argue that this number is not exhaustive - further research may well disclose additional practices and devices to enable balancing regionalism. This is because they have been developed inductively, by deriving them from events and specific instances over time. The three mechanisms we have identified are the following:

- Suggesting dialogue and cooperation between two regional platforms to which a specific state belongs or cooperates with; we may call this bridging;

- Fostering simultaneous cooperation projects in two or more regional groups, especially if these different groups are led by different hegemons; this is dovetailing;

- Promoting a specific identity, associated with a specific regional grouping in a specific moment of time, for instrumental purposes - this may be called branding.

Having clarified the concept of 'balancing regionalism' and its two analytical components as well as the mechanisms underpinning it, the paper moves on to sketch out the theory behind it before looking at specific instances in the subsequent section.

\section{Central Asia and Balancing Regionalism}

Most literature represents the relationship between Central Asian states and Russia as one of dependence (see, for example, Cameron and Orenstein 2012, Laruelle 2012, Snetkov 2012, Kaczmarska 2015b) - but do not capture the recent, more subtle dynamics. Neither does the New Great Game narrative which oversimplifies relations with outside powers and Central Asian states and fits it into clashes of great powers. First of all, there is a distinction of Russia's foreign policy towards Central Asia in 1990s and early 2000s. Russia had confused interests in and undefined policy with the region and lack of military and economic capacity to protect its so-called sphere of influence, and in general its priority was turned towards integration with the West. (Cummings, 2001, p. 145; Trenin, 2009). The use of 'balancing regionalism' by Central Asian states became more acute after the shift of Russia's foreign policy towards the 'near-abroad' and, especially, after the Russo-Georgian war of 2008 and continued after the conflict in Ukraine in 2014. These two major geopolitical events tested alliances, challenged multi-vector foreign policy strategy and made Central Asian governments concerned over assertive Russia's policies. 
We suggest looking in more detail on Russia's involvement with Central Asian states in the areas of security and economy, as these are often considered the domains of international relations in which balancing behaviour is to be seen (Cooley et al. 2019). This overview will lay the foundation in the analysis of how Russia's revisionist policies are being imposed on Central Asian states through various channels, but also how regional states are containing them. We review the memberships in several regional organisations and how Central Asian states utilise their platforms.

The security domain in Central Asia, for example, is undoubtedly monitored by Russia - one needs to look at security agreements and organisations operating in the region. The Collective Security Treaty Organisation (CSTO), a Russian-led initiative, provides a framework for coordinated work among its members on security matters (counter-terrorism, for example). What is commonly understood as a 'failure' of the CSTO to quell protests and clashes in Osh in 2010, after the destitution of Kurmanbek Bakiyev and the ignition of ethnic clashes in southern Kyrgyzstan, is in fact an example of 'balancing regionalism' at play. As a matter of fact, while it is true that Kyrgyz interim president Roza Otunbayeva wrote directly to then president Medvedev for intervention, not only regional member states such as Kazakhstan, Uzbekistan and Tajikistan (all, notably, sharing borders with Kyrgyzstan) opposed sending troops to the violence-torn country, but keenly invited other regional platforms, most notably the OSCE (Kazakhstan) and the SCO (Tajikistan) to deal with the conflict (Aris 2012). Ultimately, considerations for sovereignty and non-interference prevailed, something that was paramount especially given Russia's actions in Georgia the year before. ${ }^{8}$

The principles of sovereignty and non-intervention that are solidified through the CSTO framework are being circumvented under the ideational change in Russia, especially after the annexation of Crimea. The civilisational identity that Russia is promoting with the help of discourses on 'Russian world', 'compatriots rights' through such platforms as CSTO (Allison 2017), Eurasian integration (especially connecting to Dugin's ideas of Eurasianism) (Laruelle, 2006) create a clash with Central Asian states. Russia's suggestion of the deployment of CSTO peacekeeper forces in Ukraine did not find approval among Central Asian states and even further raised concerns from Russia's revisionism (Allison 2017).

In this respect, one thing that should be noted is the strong attachment to the concept of sovereignty that one can find among Central Asian states. Thus, when United Nations' General Assembly was voting on the validity of the Crimean referendum, Central Asian states presented a different position to a Russian one. Kazakhstan and Uzbekistan abstained, and the other three did not vote. ${ }^{9}$ Another similar example could be when Kazakhstan abstained from the Russian-sponsored resolution on Syria at the Security Council (Kumenov 2018). These are illustrative examples of the result of balancing

\footnotetext{
${ }^{8}$ Roger McDermott, 'CSTO Rapid Reaction Exercises Get Off To Discouraging Start', Radio Free Europe Radio Liberty (27 August 2009)), online at < www.rferl.org/content/CSTO Rapid Reaction Exercises Get Off To Discouraging Start/1808735.h $\mathrm{tml}$

9 'Kazakhstan, Uzbekistan abstain from UN resolution on territorial integrity of Ukraine, Kyrgyzstan and Tajikistan did not vote', AKIpress, 28 March 2014, available at:

https://akipress.com/news:538310/, accessed 20 July 2018.
} 
regionalism, by not aligning with any perspective on the issue matter and having necessity to juggle different national interests, with a strong sentiment towards sovereignty and territorial integrity.

The SCO is another security framework operating in the Eurasian space and is referred to as a Russia-China led organisation. The SCO's efforts in security management in the region are questionable (Aris and Snetkov 2013, p. 205), however, this could be explained in the emphasis of sovereignty and non-interference among the SCO's members and a cooperative/trust-building nature of the organisation. The SCO serves as a platform of 'cross-civilisational dialogue' which is starkly different to the one centered on Eurasia and promoted by Russia. Although, SCO traditionally covers hard security questions of border protection, territorial delimitation, fight against terrorism, extremism, drug trafficking and crime, it also recently been used as a medium for economic cooperation. Whereas Russia distinguishes between security organisation (CSTO) and economic one (EAEU), for China SCO functions as a general framework and economy is linked to security (Dadabayev, 2014). SCO also saw an increase in the geography of its members by accepting India (another emerging regional power) and Pakistan in 2017.

In the economy sector, despite the emphasis placed on the EAEU, Russia is not the first trading partner for some Central Asian states (not even second for some), and, hence, presents not a prioritised place. In Kazakhstan, Italy and China (the EU as collective is the major trading partner) have by far bigger percentage of export trade. ${ }^{10}$ In Kyrgyzstan, Russia is third after Switzerland and Kazakhstan, in Uzbekistan it is fourth. ${ }^{11}$ Only in Turkmenistan (the latest figures on Turkmenistan are hard to find) and Tajikistan Russia is the first trading partner. ${ }^{12}$ Furthermore, the Central Asian states have signed the Enhanced Partnership Agreement with the EU, which focuses on economic cooperation and trade.

Being members of multiple regional organisations and structures gives opportunity to Central Asian states to utilise 'balancing regionalism' tool. Seeing the shortcomings of each organisation and juggling increasing interests of not only Russia, but also China, Central Asian states are resorting to multilateral cooperation on a regional basis making sure to balance Russia's assertive behaviour by increasing costs for a potential aggressive behaviour. But how would costs increase and brokerage be more complex?

Balancing regionalism allows for the existence of a complex web of norms simultaneously at play - the revisionist state deals with neighbours that belong to different multilateral platforms where norms' interpretation clashes with that of the revisionist itself; through the incorporation of great powers in regional platforms, states link regional issues and problems to the international level - potential revisionism assumes more international visibility and strategic importance; within multiple regional platforms, states play out different identities to display normative conformity and gain legitimacy - a revisionist policy based on civilisational

${ }^{10}$ Kazakhstan exports, imports and trade balance By Country 2016, 2018, available at: https://wits.worldbank.org/CountryProfile/en/Country/KAZ/Year/2016/TradeFlow/EXPIMP/Partner/bycountry, accessed 20 July 2018.

11 Uzbekistan Trade Statistics, 2018, available at: http://www.economywatch.com/economicstatistics/Uzbekistan/Trade Statistics/, accessed 20 July 2018.

12 Tajikistan Exports by Country, 2018, available at: https://tradingeconomics.com/tajikistan/exportsby-country, accessed 20 July 2018. 
grounds is therefore undermined and delegitimised more easily; different regional platforms pursue different, often overlapping agendas - pursuing an offensive agenda with respect to a regional group may undermine the revisionist's position in another group by virtue of the linkages that exist between groups, thus making brokerage more difficult. This last point, in particular, rests on recent research conceiving of regional platforms not as 'atomistic entities that take decisions largely in isolation from each other' but rather as 'being interdependent' (Jetschke and Lenz 2013; for an interesting parallel with respect to East Asia and how small states there balance against surrounding great powers, see Goh's notion of 'omnienmeshment' (2005)). We argue that this happens by means of the three mechanisms of bridging, dovetailing, and branding, which is what we turn to now.

\section{Bridging}

Central Asian leaders and officials expressed on numerous occasions the need to bring closer different regional organisations. Former President Nazarbayev proposed that SCO should cooperate more with other international organisations, such as the UN, CSTO and CICA (Conference on Interaction and Confidence-Building Measures in Asia). ${ }^{15}$ Kyrgyzstan and Tajikistan have long stressed that their participation in CSTO, SCO, and CIS strengthens their (inter)national security policies, and more coordination between CSTO and SCO was invoked especially after Crimea (de Haas, 2017). This was due to the fact that later in 2014, Bordyuzha claimed that hypothetically CSTO peacekeeping forces could be deployed in Ukraine as 'they can be deployed inside CSTO members and beyond their borders' (Allison 2017, p. 130) thus eliciting fears about separatism and intervention in other CSTO members.

It is in this spirit that also at the plenary meeting in Vienna under Tajikistan's Chairmanship in July 2019 the SCO Secretary-General, EU Special representative for Central Asia and OSCE Secretary-General were invited to discuss the future of cooperation between all three organisations, especially in the areas of security. ${ }^{16}$

Kazakhstan called for greater cooperation between economic entities as well. Thus, for example the country's officials expressed the idea of cooperation between the EAEU and EU with the aim of creating a single economic space from Atlantic to Pacific. ${ }^{17}$ In addition, Nazarbayev also suggested that SCO, EAEU and EU could integrate into common economic space. At the last summit of the EAEU in Bishkek in 2019, Nazarbayev highlighted the need to expand the organisation's cooperation with ASEAN to make the 'Eurasian space more global'. ${ }^{18}$ On the same line seems to have been Tajikistan. Rashid Alimov, SecretaryGeneral of the SCO in 2016-2019, argued already in 2014 and then during his tenure at the SCO that the Belt and Road project and the EAEU were 'compatible and should be combined', allegedly to resist Russia's pressure to join the bloc (Nourzhanov 2018, pp. 9596).

\footnotetext{
${ }^{15}$ Central Asia General Newswire, April 6, 2017 Thursday, Nazarbayev calls for expanding SCO cooperation with international organizations.

16 Tajikistan Newsline (English), July 16, 2019 Tuesday, OSCE, SCO and EU in Central Asia discuss cooperation in Vienna under Tajikistan chairmanship

$17 \mathrm{http}: / / \mathrm{mfa} . g o v . k z / e n / a t h e n s / c o n t e n t-v i e w / k a z a k h s t a n-a d v o c a t e s-c l o s e r-t i e s-b e t w e e n-e u-a n d-$ eurasian-economic-union

$18 \mathrm{http}: / / \mathrm{mfa} . g o v . k z / f i l e s / 5 c f 22 f a 5 d 4 e e 2 . p d f$
} 
The ideas for bridging different organisations together is not only rhetorical. CICA itself was built as an equivalent of the OSCE and is designed to discuss issues of security and stability in Asia and includes a vast plethora of partners, such as the UN, OSCE, Arab League, Parliamentary Assembly of Turkic Speaking Countries. Nazarbayev wished for the merging of OSCE and CICA to have a single organisation for sub-continent. ${ }^{19}$

\section{Dovetailing}

Dovetailing began already in the aftermath of the Georgian war in 2008, when the Central Asian states, silent within the CSTO, raised issues pertaining to sovereignty within the SCO. In the Dushanbe meeting 2008, the Central Asian republics refused to back Russia's actions in the north Caucasus in the name of norms pertaining to non-intervention and territorial integrity, aligning themselves with China despite Medvedev's hopes for endorsement. The same issue was purposefully presented on two tables, to get more political and legitimacy clout and show Russia that a complex regional set of norms was at play (Freire 2011, p. 72; Cooley 2012).

Thus, the multiplicity of regional organisation also gives opportunity to further promote national interests, as for instance, was stated by President Jeenbekov in regard to the country's membership in SCO and CSTO and their awaited coordination in the field of security. ${ }^{20}$ This is a prevalent feeling among other Central Asian states which all explore to further collaboration on particular areas with different regional organisations.

For example, the meeting of foreign ministers of CSTO in Bishkek was discussing the issues on reduction of tensions on Tajik-Afghan border and the collective plan to implement the UN Counter-Terrorism Strategy 2019-2021, as well as an appeal to NATO member states to strengthen cooperation. This meeting was followed by a meeting with a similar format of the SCO, where the issues of terrorism, illicit drug trafficking and regional conflict settlement. ${ }^{21}$ After the summit of the heads of states of the SCO in Bishkek, many leaders went to CICA summit in Dushanbe to raise similar issues. ${ }^{22}$ In this way, common problems and concerns are discussed at different formats with different set of actors, almost simultaneously.

A dovetailing mechanism could be noted also in the diversification of relationship between Central Asian states and other countries. The format of five Central Asian states plus another one (USA, Japan, South Korea, to name the few) is a common framework to discuss common issues and develop strategies. Since 2006, Kazakhstan annually hosts military exercises called 'Steppe Eagle' together with NATO and other regional partners. ${ }^{23}$ Such

\footnotetext{
${ }^{19}$ Central Asia General Newswire, November 16, 2017 Thursday, Nazarbayev declares wish to unite CICA, OSCE.

${ }^{20}$ Central Asian News Service (English language) April 30, 2019 - President Jeenbekov meets CSTO Defense Ministers

21 https://astanatimes.com/2019/05/kazakh-fm-meets-with-kyrgyz-president-fm-and-attends-csto-scomeetings-in-kyrgyzstan/

22 Putz, C., June 13, 2019 - The Shanghai CooperationOrganization Summit Kicks Off in Bishkek., available at https://thediplomat.com/2019/06/the-shanghai-cooperation-organization-summit-kicks-offin-bishkek/, accessed on 7 September 2019.

${ }^{23} \mathrm{https}: / /$ www.nato.int/cps/en/natohq/topics_107957.htm
} 
exercises are used for personnel training and, especially for peacekeeping forces, and are aimed at potential deployment in the events of crises.

\section{Branding}

In response to Russia's version of Eurasianism and regional integration, Central Asian states also offered their views on the new regional identities. This is important to note, since as noted above Russia's revisionism features a specific manifestation that lies in a civilisational understanding of borders and sovereignty. Such understanding of these fundamental institutions of international order are visible in the words of Alexander Dugin, the influential political philosopher and theorist of contemporary Russian Eurasianism: 'It is as dangerous to stop the geopolitical offense in the post-Soviet space, as to simply retreat...Expansion is the law of Russia's existence. It is doomed to be either an empire, or not to exist at all' (quoted in Polikanov 2012, p. 82).

At the forum on One Belt, One Road, Nazarbayev proposed an idea of 'Big Eurasia' which is based on 'the Economic Belt of the Silk Road that could integrate the platforms of the SCO, EEU and EU into a common prosperous region'. ${ }^{24}$ Two years earlier a similar idea for creation of Great Silk Road by connecting the EAEU, SCO and BRICS, thus bringing together the East and West and fostering global trade. ${ }^{25}$

In the interactions with the EU, Central Asian states rhetorically emphasise 'European values' that are strengthened through cooperation on democratic reforms. ${ }^{26}$ Such interactions also symbolise the support to the statehood, as was stated by Kyrgyz President Jeenbekov in his remarks regarding the role of the OSCE in the country's path to Parliamentary democracy and reforms. ${ }^{27}$

The latest trend in regional cooperation is the vector of Central Asian cooperation without the presence of external powers, thus enhancing a separate 'Central Asian group' in which the surrounding great powers cannot fully take stakes. This platform was launched through the informal meeting of the heads of state of Central Asian states first in Astana in 2018. The idea was presented by President Mirziyoyev and instantly supported by Kazakhstan. Nazarbayev noted that there is a broad range of topics that Central Asian states can discuss alone regional issues among themselves by virtue of being 'Central Asian'. ${ }^{28}$ If anything, as mentioned in the course of the paper, Central Asian leaders are vocally against overstretching the agendas and mandates of the organisations, contrary to Russia's wishes.

In sum, regional organisations and/or initiatives are either imposed/offered or initiated by Central Asian states themselves. This, subsequently, results in a multiplicity of norms

${ }^{24}$ Kazakhstan General Newswire, May 15, 2017, Silk Road Economic Belt could link SCO, EEU and EU - Nazarbayev.

${ }^{25}$ Kazakhstan General Newswire, July 10, 2015, EEU, SCO and BRICS could form a common trade area - Nazarbayev.

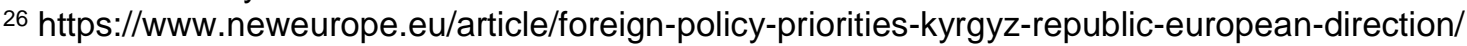

27 Central Asia General Newswire, May 22, 2018 Tuesday, Jeenbekov reaffirms OSCE Secretary General that Kyrgyzstan committed to developing parliamentary democracy.

28 'Rare Central Asian Summit signals regional thaw,' RadioFreeEurope/RadioLiberty, 15 March 2018, avalable at: https://www.rferl.org/a/central-asian-summit-astana-kazakhstan-uzbekistan-tajikistankyrgyzstan-turkmenistan/29101686.html, accessed 20 July 2018. 
emanating from these organisations. Engaging with diverse range of regional identities and normative frameworks helps Central Asian states appeal to various regional actors if necessary, by means of bridging such organisations, dovetailing issues in them, and branding themselves as 'belonging' to a specific set of identities and ideas. This creates a tapestry of identities, norms that set the condition for Russia's revisionism to be aware of and difficulties for it to leverage. In other words, relying on the theoretical framework illustrated above, 'brokerage' and 'access' are made more difficult.

\section{[Table 1: Formal and informal regional groups in Eurasia]}

\section{Conclusions}

Russia is pursuing revisionist policies across the globe, and Central Asia is not immune from the threats emanating from them. To account for how the region tames revisionist influences and fends off Russia's aggressive behaviour, the paper has made the case to introduce the concept of 'balancing regionalism'. By joining different regional groups, voicing different regional identities, creating multiple regional narratives and linking different regional platforms together, the Central Asian states are trying to embroil Russia in a complex scheme of norms, identities, membership, incentives, and costs that make revisionism more difficult to pursue and, more importantly, legitimise. As has been said, to sustain a revisionist course of foreign policy, intentions alone are not sufficient - 'a state also must be able to mobilise significant material and ideological resources in pursuit of its aims. Ironically, access to these resources depends on the very institutional system a revisionist hopes to overturn' (Goddard 2018, p. 2).

Importantly, the argument presented in this paper does not predict that 'balancing regionalism' will prevent Russia from pursuing a revisionist foreign policy in Central Asia, nor assumes that Russia will necessarily do so. Simply and humbly, the framework outlined here sheds light on the complex structures and dynamics that would make regional revisionism more costly, more difficult, and less legitimate. As has been argued, 'in the face of the Eurasian mosaic regarding political options, security goals, and economic orientations, Russian foreign policy faces a complex arena of differentiated interests that are very often in competition with one another' (Freire 2011, p. 72). This tells us that in the international politics of Eurasia 'answers to regional dynamics lie in local history and politics, in the details of the imperial dissolution rather than the insights from a general theory' (Wohlforth 2004, p. 232) and that 'the only way to make sense of the pattern of strategic responses in the area is to delve deeply into the domestic and local politics of all the actors involved' (2004, p. 235). While in this paper it was not possible to 'delve deeply' in domestic and local politics, the hope is that further research will elaborate more on 'balancing regionalism' enriching it with insights coming from sub-systemic levels of analysis.

A further hope that we have is that the notion of 'balancing regionalism' will offer a fresh perspective on regionalism in Central Asia and, by extension, Eurasia. Frequently described as 'failed', 'virtual', or 'non-cooperative' (Allison 2008), the notion of balancing regionalism and its mechanisms may well help make sense of a less ambitious, more conservationist and strategic kind of regionalism, aimed at balancing powerful neighbours by embroiling 
them in a series of multilateral platforms, thus ensuring the survival of local regimes and maintaining states' sovereignty intact. Bridging, dovetailing and branding demonstrate how Central Asian states engage with their international partners, utilise different regional platforms, and attempting to connect Russian-led initiatives with those of China and Europe. In this way, the notion of balancing regionalism may become a useful theoretical concept to make sense of the domestic-international nexus, and has the merit to focus on regionalism not as a goal, not just as a process, but rather as a foreign policy tool, akin to what Ruland has dubbed 'diminished multilateralism' (2018, pp. 10-1).

Finally, the concept of 'balancing regionalism' may help shed light on the agency of Central Asian states, too often sacrificed on the altar of the 'New Great Game' narrative. In sum, balancing regionalism may still be an underdeveloped theoretical tool in need of refinement, but its utility and benefit when it comes to explaining Russia's revisionism in Central Asia has certainly potential. Further research may look at how domestic politics plays into it, what structural and idiosyncratic factors influence its success or failure, and how it is applicable in other parts of the world.

\section{References}

Acharya, A., 2014. The End of American World Order. Cambridge Malden: Polity Press. Allison, R., 2008. Virtual Regionalism, Regional Structures and Regime Security in Central Asia. Central Asian Survey, 27 (2), 185-202.

Allison, R., 2017. Russia and the Post-2014 International Legal Order: Revisionism and Realpolitik. International Affairs, 93 (3), 519-543.

Aris, S. 2012. The Response of the Shanghai Cooperation Organisation to the Crisis in Kyrgyzstan, Civil Wars, 14(3), 451-476.

Aris, S. and Snetkov, A., 2013. 'Global Alternatives, Regional Stability and Common Causes': The International Politics of the Shanghai Cooperation Organization and Its Relationship to the West. Eurasian Geography and Economics, 54 (2), 202226.

Bull, H., 1977. The Anarchical Society: A Study of Order in World Politics. Fourth edi. New York: Palgrave Macmillan.

Cameron, D.R. and Orenstein, M. a., 2012. Post-Soviet Authoritarianism: The Influence of Russia in Its 'Near Abroad'. Post-Soviet Affairs, 28 (1), 1-44.

Contessi, N., 2015. Foreign and Security Policy Diversification in Eurasia: Issue Splitting, Co-alignment, and Relational Power. Problems of Post-Communism, 62(5), 299-311.

Cooley, A. 2012. Great Games, Local Rules. New York: Oxford University Press.

Cooley, A. 2019. Ordering Eurasia: The Rise and Decline of Liberal Internationalism in the Post-Communist Space. Security Studies, 28 (3), 588-613

Cooley, A., Nexon, D. and Ward, S. Revising order or challenging the balance of military power? An alternative typology of revisionist and status-quo states. Review of International Studies, on-line first.

Cornell, S.E. and Engvall, J., 2017. Kazakhstan in Europe: Why not? Stockholm.

Costa Buranelli, F., 2017. Spheres of Influence as Negotiated Hegemony - The Case of Central Asia. Geopolitics, 0 (0), 1-26. 
Cummings, S., 2001. Happier Bedfellows? Russia and Central Asia under Putin. Asian Affairs, 32(2), 142-152.

Dadabayev, T. 2014. Shanghai Cooperation Organization (SCO) Regional Identity Formation from the Perspective of the Central Asia States. Journal of Contemporary China 23(85), 102-118.

Dadabaev, T., 2019. Uzbekistan as Central Asian game changer? Uzbekistan's foreign policy construction in the post-Karimov era. Asian Journal of Comparative Politics, 4(2), 162-175.

David, S.R., 1991. Explaining Third World Alignment. World Politics, 43 (2), 233-256.

De Haas, M. 2016. War Games of the Shanghai CooperationOrganization and the Collective Security Treaty Organization: Drills on the Move!, The Journal of Slavic Military Studies, 29(3), 378-406.

De Haas, M., 2017. Relations of Central Asia with the Shanghai Cooperation Organization and the Collective Security Treaty Organization, The Journal of Slavic Military Studies, 30(1), 1-16.

Freire, M.R., 2011. USSR/Russian Federation's Major Power Status Inconsistencies. In: T.J. Volgy, R. Corbetta, K.A. Grant, and R.G. Baird, eds. Major Powers and the Quest for Status in International Politics: Global and Regional Perspectives. New York: Palgrave Macmillan US, 55-76.

Fumagalli, M., 2007. Alignments and Realignments in Central Asia: The Rationale and Implications of Uzbekistan's Rapprochement with Russia. International Political Science Review, 28 (3), 253-271.

Goddard, S.E., 2018. Embedded Revisionism: Networks, Institutions, and Challenges to World Order. International Organization, 1-35.

Goh, E. 2005. Great powers and Southeast Asian Regional security strategies: omnienmeshment, balancing and hierarchical order. RSIS Working Papers; 84/05, Nanyang Technological University.

Goh, E., 2008. Great Powers and Hierarchical Order in Southeast Asia: Analyzing Regional Security Strategies. International Security, 32(3), 113-157.

Hameiri, S., 2013. Theorising Regions Through Changes in Statehood: Rethinking the Theory and Method of Comparative Regionalism. Review of International Studies, 39 (2), 313-335.

Jetschke, A. and Lenz, T., 2013. Does Regionalism Diffuse? A New Research Agenda for the Study of Regional Organizations. Journal of European Public Policy, 20 (4), 626-637.

Kaczmarska, K., 2015a. Russia's Droit de Regard: Pluralist Norms and the Sphere of Influence. Global Discourse, 5 (3), 434-448.

Kaczmarska, K., 2015b. Russia's droit de regard: pluralist norms and the sphere of influence. Global Discourse, 5 (3), 434-448.

Kourmanova, A., 2015. Kazakhstan and the WTO: A New Era [online]. CSIS. Available from: https://www.csis.org/analysis/kazakhstan-and-wto-new-era [Accessed $20 \mathrm{Jul}$ 2018].

Kumenov, A., 2018. Kazakhstan Gets Russian Flak Over UN Syria Vote [online]. Eurasianet.org. Available from: https://eurasianet.org/s/kazakhstan-gets-russianflak-over-un-syria-vote [Accessed 20 Jul 2018].

Laruelle, M. 2006. Aleksandr Dugin: A Russian Version of the European Radical Right? Kennan Institute Occasional Paper 294. 
Laruelle, M., 2012. When the "Near Abroad" Looks at Russia: the Eurasian Union Project as Seen from the Southern Republics. Russian Analytical Digest, 112, 811.

Laruelle, M. and Peyrouse, S., 2012. Regional Organisations in Central Asia: Patterns of Interaction, Dilemmas of Efficiency. Bishkek, No. 10.

Little, R., 2007. The Balance of Power in International Relations: Metaphors, Myths and Models. Cambridge: Cambridge University Press.

Makarychev, A., 2014. Security Agenda in Russia: Academic Concepts, Political Discourses, and Institutional Practices. In: M. Kaldor and I. Rangelov, eds. Handbook of Global Security Policy. Chichester: Wiley-Blackwell, 408-425.

Mikhaylenko, E., 2016. Revisionist Regionalism of the Russian Federation in the PostSoviet Space. Analele Universitatii din Craiova - Seria Istorie, 21 (1), 77-86.

Morozov, V., 2015. Aimed for the Better, Ended up with the Worst: Russia and International order. Journal of Baltic Security, 1 (1), 26-36.

Nourzhanov, K., 2012. Omnibalancing in Tajikistan's Foreign Policy: Security-Driven Discourses of Alignment with Iran. Journal of Balkan and Near Eastern Studies, 14 (3), 363-381.

Nourzhanov, K. 2018. Tajikistan's multi-vector foreign policy: constructing relations with Russia, China, and the United States. In Tajikistan on the move: statebuilding and societal transformations. Lexington Books.

Ohayan, A. (ed.) 2018. Russia Abroad: Driving Regional Fracture in Post-Communist Eurasia and Beyond. Georgetown University Press.

Paul, T.V. (ed.). 2016. Accommodating Rising Powers - Past, Present and Future. Cambridge: Cambridge University Press.

Polikanov, D., 2012. The Russian Bear. In: Multipolarity in the 21st Century - a New World Order. Abingdon: Routledge, 80-106.

Putz, K., 2018. Tajikistan Still Considering Engagement with the Eurasian Economic Union [online]. The Diplomat. Available from: https://thediplomat.com/2018/04/tajikistan-still-considering-engagement-with-theeurasian-economic-union/ [Accessed 20 Jul 2018].

Richey, M., 2018. Contemporary Russian Revisionism: Understanding the Kremlin's Hybrid Warfare and the Strategic and Tactical Deployment of Disinformation. Asia Europe Journal, 16 (1), 101-113.

Ruland, J., 2018. 'Principled Multilateralism' versus 'Diminished Multilateralism:' Some General Reflections. In: Multilateralism in a Changing World Order. Singapore: Konrad Adenauer Stiftung, 1-12.

Sakwa, R., 2017. Единая Европа или никакой: деградация и многовекторность. Polis, 8-24.

Sakwa, R., 2019. Russian Neo-Revisionism, Russian Politics 4, 1-21.

Schweller, R. 2015. Rising Powers and Revisionism in Emerging International Orders. Valdai Papers, no. 16, May 2015.

Slobodchikoff, M. 2014. Building Hegemonic Order Russia's Way: Order, Stability, and Predictability in the Post-Soviet Space. Lanham, NY: Lexington.

Snetkov, A., 2012. When the Internal and External Collide: A Social Constructivist Reading of Russia's Security Policy. Europe - Asia Studies, 64 (3), 521-542.

Sorensen, G., 2016. Rethinking the New World Order. London: Palgrave Macmillan. 
Teles Fazendeiro, B., 2018. Russian-Uzbekistani Relations. In: Uzbekistan's Foreign Policy: The Struggle for Recognition and Self-Reliance under Karimov. Abingdon: Routledge, 67-91.

Thomas, D.C., 2017. Beyond Identity: Membership Norms and Regional Organizations. European Journal of International Relations, 23 (1), 217-240.

Trenin, D., 2009. Russia Reborn: Reimagining Moscow's Foreign Policy. Foreign Affairs, 88(6), 64-78.

Waltz, K.N., 1979. Theory of International Politics. Long Grove: Waveland Press, Inc.

Wight, M., 1977. Systems of State. London: London School of Economics and Political Science.

Wivel, A. and Waever, O. 2018. The Power of Peaceful Change: The Crisis of the European Union and the Rebalancing of Europe's Regional Order. International Studies Review, 20(2), 317-325.

Wohlforth, W.C., 2004. Revisiting Balance of Power Theory in Central Eurasia. In: Balance of Power - Theory and Practice in the 21st Century. Stanford, CA: Stanford University Press, 214-238. 